\title{
EXPLORING THE HIDDEN CUSTOM OF PUKHTUNWALI WITH REFERENCE TO CONFLICT RESOLUTION AMONG PUKHTUN SOCIETY
} Habib ur Rahman ${ }^{1^{*}}$, Humera Jamal ${ }^{2}$, Younas Khan ${ }^{3}$, Waqar Ahmad ${ }^{4}$, Abdullah ${ }^{5}$

${ }^{1 *}$ Ph.D., Scholar, Department of Rural Sociology, The University of Agriculture Peshawar, KPK, Pakistan; ${ }^{2}$ Lecturer, Department of Rural Sociology, The University of Agriculture Peshawar, KPK, Pakistan; ${ }^{3}$ Lecturer in Sociology, Department of Sociology and Political Science, Bacha Khan University Charsadda, KPK, Pakistan; ${ }^{4}$ Lecturer in Sociology, Department of Sociology, The University of Sawabi, KPK, Pakistan; ${ }^{5}$ Lecturer in Sociology, Department of Sociology and Political Science, Bacha Khan University Charsadda, KPK, Pakistan.

Email: ${ }^{1 *}$ habibhay@gmail.com, ${ }^{2}$ humerajamal@aup.edu.pk, ${ }^{3}$ youniskhan@bkuc.edu.pk, ${ }_{5}^{4}$ waqaryousafzai99@gmail.com, 5 abdullahsoc3@gmail.com

Article History: Received on $31^{\text {st }}$ May 2021, Revised on $25^{\text {th }}$ June 2021, Published on $29^{\text {th }}$ June 2021

\begin{abstract}
Purpose of the study: The purpose of the current study is designed to explore the hidden custom among Pukhtuns' society (Nanawati) as a traditional mechanism for conflict resolution.

Methodology: A cross-sectional-based research design was conducted with the sole aim to explore the role of Nanawage in the conflict resolution process among Pukhtun inhabitants in District Dir Lower Khyber Pukhtunkhwa. The potential sampled respondents of the study were household heads particularly elders/ Jirgmar (mediators)/ religious leaders/ and those who practiced and observed Nanawate as the traditional mechanism of conflict resolution from 217 respondents out of 420 Household Head as per Sekaran (2003) criteria through proportional allocation method. Descriptive (univaraite) and inferential statistics (bivaraite analysis) was used to ascertain the level of association among practiced of Nanwati (independent variable) and conflict resolution (dependent variable) through the application of chisquare test statistics.
\end{abstract}

Main Findings: Based on the results Nanawate is widely practiced by Pakhtun inhabitants locally by the virtue of gray beard (Speengeries), religious clergies (Mullas), and family head. Moreover, religion also plays a vital role as a mediator among two party's conflicts through the perpetuation of Nanawate as it to be believed satisfactory, while not the rejection of Nanawate by someone may consider as damnation on that party who negated the contribution of the religious institution.

Applications of this study: Exposing the role of Nanawate in terms of conflict resolution particularly is the order of the day through awareness and social media at the macro (government/ non-government sectors) and micro-level (familial and community level), with the collaboration of by giving a legal status in judiciary system will dethrone the conflicting situation among local inhabitants through the hidden custom of Nanawate were put forward some of the recommendations in light of the present study.

Novelty/Originality of this study: This study is designed to explore the hidden custom deliverance of Nanawate (a traditional mechanism) in conflict resolution with reference to Pakhtun's society through perceptional based study, along with quantitative research designs to measure the association between the practicing of Nanawate in conflict resolution system among Pakhtun's tribe.

Keywords: Conflict Resolution, Gray Beard, Nanwati, Pukhtunwali, Role of Clergy, Jirga.

\section{INTRODUCTION}

The Jirga, throughout the long term, has filled in as the essential device of compromise for Pashtuns in Pakistan's ancestral regions, once known as the Federally Administration Tribal Areas (Yousaf and Rasheed, 2018). Despite the fact that pilgrim and post-frontier legitimate and managerial structures have generally sabotaged the Jirga and the Pashtun culture, different instances of tribal drives through Jirga and Jirga-based Lashkars (ancestral harmony state armies), since 2001, show that Jirga can, in any case, assume a significant part in long haul harmony in Pakistan's tribal regions (Yousaf and Poncian 2018). Late fosterments in the order and grant of harmony and compromise additionally point towards the way that such social instruments and constructions are really suffering and practical on the grounds that they are inserted in the social fortitude bonds and natural perspectives of the important gathering. Moreover, these native techniques for peacemaking are submerged in friendly minds and social rationalities, which will ensure support capable harmony in such social orders and locales (Yousaf and FurrukhZad 2020).

The Higaunon clan in the Philippines likewise utilizes its ancestral gatherings to address local conflicts and issues that go under its ward (Cabanes, 2017). The contention between Oku Iboku and Ikot Offiong clans of Nigeria somewhere in the range of 1987 and 2005 was settled utilizing native strategies for compromise (Peter, 2017). A social mechanism for compromise, arrangement, and intervention. Jirga, as in numerous ancestral social orders that utilization native compromise and change strategies is established in the Pashtun society's practices and assumes a significant part in keeping everything under control and congruity among the Pashtun clans. Indeed, even with the scant recorded history of 
Pashtun Jirga, it generally concurs that the Jirga is the most long-term design of the Pashtun lifestyle (Ahmed and Yousaf, 2018).

The Jirgas are administered by ancestral seniors, known as the masharan, where issues going from homegrown and ancestral contentions to territorial and public governmental issues are talked about (Khan and Saeed, 2017. The Pashtun history proposes that the Jirga has consistently held a significant spot in the socio-political issue of the Pashtun society (Ahmed and Yousaf, 2018). Notwithstanding, the ancestral mechanism of Jirga and Lashkars (harmony local armies) against the Taliban recommend that these native compromise and change devices actually can possibly assume a part towards accomplishing tough harmony in the area (Yousaf and Poncian 2018). The ancestral Jirga's significance towards the Pashtun ancestral society was additionally seen as a danger by the Taliban and other assailant bunches in the district. Hence, these gatherings have taken a stab at assuming control over this Pashtun dynamic design in the ancestral regions (Braithwaite and D'costa, 2018).

As noted before, the job of older folks in compromise in African social orders is more significant today in light of the disappointment of standard (or western) compromise techniques. This nonetheless, doesn't imply that conventional and native techniques or procedures are immaculate; it rather implies that some advancement might be made in compromise if customary systems are viably used as well. In this part, we take a gander at the job of conventional compromise methodologies (by zeroing in on the establishment of older folks) in settling extractive asset clashes in Tanzania (Must, 2018). Harmony specialists currently demand investigating the capability of native compromise techniques that include local systems and customary constructions (Brigg and Walker 2016).

These customary designs keep on assuming a huge part inside rustic ancestral regions in the area. Pashtun 'ancestral' networks, generally without the advanced equity framework, actually hold fast to these foundations. The job and the effect of these social organizations can be checked by the way that nearby state organizations and military have consistently associated and composed with different neighborhood clans through these designs; in any case, the state additionally avoided fusing these foundations inside the bigger system of harmony and compromise in the area (Yousaf and FurrukhZad 2020).

Pashtuns ${ }^{1}$ are an ethnic gathering situated in both Afghanistan and Pakistan, with exonyms like Afghan, Pashtoon, Pushtoon, Pathan, and Pukhtoon (every one of these are various terms utilized for Pakhtune), additionally utilized for the gathering (Ahmed, 2013; Siddique, 2014). In Pakistan's Khyber Pakhtunkhwa and Balochistan territories, alongside ancestral regions on the Afghanistan-Pakistan line, the Pashtuns make up the second biggest ethnic gathering, with $15 \%$ of the populace, in the country (Ethnic Groups in Pakistan, 2018; Hadid and Sattar, 2018). The ancestral Pashtuns, situated in the Afghanistan-Pakistan line area in the north-west, have generally been portrayed as "fighter-like" and "savages," with an inclination of being vicious, in provincial writing, with contemporary writing depicting them as "supporters of aggressors" (Afsar et al., 2008; Beattie, 2011; Coughlin, 2013; Kilcullen, 2009; Wylly, 1912).

Pashtunwali $^{2}$, in a real sense deciphered as the method of the Pashtuns, is a bunch of customs, social codes, and qualities that manage the Pashtune society and its lifestyle and has been recently talked about exhaustively by different creators, even with the approach of globalization and financial turn of events, contemplates show that Pashtunwali actually holds significance for Pashtuns living in the ancestral regions (Khayyam et al., 2018). A portion of the significant Pashtun social codes incorporates Badal (vengeance and correspondence), Badragga (safe lead), Hujrah ${ }^{3}$ (a commong place where Pashtun set together, place for guests), Jirga ${ }^{4}$ (Pashtun ancestral gatherings), Lashkar (civilian armies), Melmastya (Hospitality), Nanawatay (law of asylum/pardoning), Nang (honor), and Tiga (détente), among others. A significant principle of Pashtunwali, among these, important with regards to Pashtuns and harmony is the Pashtun Jirga by and large while Nanawate especially (Yousaf, and FurrukhZad, 2020; Khan Y et al., 2018a). Pukhtoonwali is a code of standards and practices that aides and impacts the existence of Pukthoons, and subsequently the endurance systems received by them during the struggle. Pukhtoonwali is viewed as probably the best code by its followers (Alam, 2014). The Pukhtoons cling to Pukhtoonwali such a lot of that any individual who doesn't follow its standards and qualities is thought about to a lesser extent as a Pukhtoon. In Pukhtoonwali, certain qualities stand apart on account of their importance and significance among the Pukhtoons. Melmastia ${ }^{5}$, which implies cordiality, is maybe the main worth and is generally rehearsed (Alam et al, 2013). Pukhtoons liberally offer friendliness to anybody, which alongside food and haven incorporates security from hurt (Ambreen 2013). Near the worth of Melmastia is Gham-Khadi which implies the event/seasons of euphoria like the birth or marriage of somebody and seasons of distress like disease and passing. As indicated by this worth, family members, companions, and neighbors should visit each other on such events and show physical, passionate and monetary help, Rogha-Jorra is another idea that might be interpreted as a compromise or

\footnotetext{
${ }^{1}$ Tribe who speaking Pashtu language and living in Pakistan and Afghanistan.

${ }^{2}$ Pakhtunwali is the code of conduct developed by Pakhtune tribe which are applied on all their Pakhtune.

${ }^{3}$ Hujra is a common place where Pakhtune set together and discuss the issues, along with this it is a common place where the guests are entertained.

${ }^{4} \mathrm{Jirga}$ is the gathering of one or more people to set together and to resolve the disputes among Pakhtune.

${ }^{5}$ Melmastia is the term used by Pakhtune for hospitality; Melmastia is the one of the Pakhtunwali code of conduct followed by Pakhtune tribe.
} 
potentially get-together and implies the repayment of debates in the public eye, it surmises the interaction of regular and repetitive gatherings and counsel, this is an instrument for rejoining fighting gatherings with nobility and a method of setting up harmony locally (Dawar, 2017).

A Jirga, a committee of older folks (known as the Masharan), is by a long shot the main fundamental of Pashtunwali, which centers around compromise, exchange, and intervention among the Pashtun people group, the term Jirga alludes to a native debate goal and consideration component followed by the Pashtun clans for quite a long time, and furthermore received as a political establishment by Afghanistan (Ahmed and Yousaf, 2018). It is said that the Jirga directs the lifestyle for the ancestral Pashtuns where choices range from more modest issues of common clash and interest to significant issues relating to international concerns and public legislative issues, Jirga capacities when a contention emerges on nearby, ancestral, or territorial level, with ancestral older folks meeting up, sitting all around, and talking about and settling on the matter (Yousufzai and Gohar, 2005). Jirga that can likewise be known as the gathering of elderly folks is a neighborhood establishment under Pukhtoonwali. Among Pukhtoons, it's anything but a native equity framework for interceding and mediating between questioning gatherings to settle their issues (Taizi, 2007). Like Jarga is the organization of Hujra, a mutual space for rehearsing the upsides of Pukhtoonwali (Khattak, 2010). It is utilized as a position of accommodation, a native court, and a space for amusement (Ahmed and Yousaf, 2018).

\section{Nanawate}

The term Nanawate 6 is depicted by Dupree in (1980) as 'the right of refuge and the mandatory acknowledgment of a ceasefire offer'; its more exact significance is looking for absolution/pardon and the required acknowledgment of a détente offer (Atayee 1979). The Uzar, Nanawate, or admission of slip-up, is rehearsing for compromise, saying 'sorry' is normal practice all the Pakhtoon clans and it's anything but a unique inclusion while working on associating with other Pakhtoon clans. There is various sorts of Nanawate for the most part the culprit is coordinated to go to the casualty's home with Jirga individuals, female (Toor Sare) or now and again they keep bull or sheep which can be a butcher in place of casualties. When the Nanawate is acknowledged they are accommodated. Peace and hormony (Solha $\left.{ }^{7}\right)$ or compromise between the gatherings is the most successive result of a Jirga/shura hearing. Nanawate1 has a focal spot and among the Pashtonwali are establishments that expect to accommodate, redress, and reestablish harmony between the culprit, the people in question, and their quick friendly environmental factors, generally the town. The Nanawate, Uzr in Nuristani, or conciliatory sentiment, is a mind-boggling part of the goal. As seen in different bits of this report on standard laws, the custom of saying 'sorry' is normal among all Afghan clans and has a unique spot in the collaboration among individuals in all pieces of the country. The culprit should apologize. The expression of remorse can take various structures. It by and large relies upon the wrongdoing. The culprit will be approached to go, for certain older folks from the town or individuals from the Jirga to the place of the person in question, with a bull or a sheep. When the gatherings take part in Nanawate (or statement of regret), they are accommodated (ILF 2004).

\section{Practitioners of Nanawate}

The term Nanawate signifies "entering" or 'going into' alludes to access to a Pashtun's home with the motivation behind looking for security or refuge in life. At that point, it turns into an impulse for the host to give him that security or conciliatory sentiment even at the expense of his/her life. A few authors have clarified Nanawate as the gift of refuge to compelling or accommodation criminals. In any case, the issuing of haven or shelter is a stand-out component of Nanawate while its precise significance and genuine soul appear to have been disregarded. In actuality, it is an approach to end long-haul extraordinary debate and wicked quarrels and to changes enmity into kinship. Under Nanawate a fighting groups resume tranquil when a contrite foe is overlooked and the well-disposed relations stay typical. At the point when a man understands that he was on the wrong in executing or harming another individual, he goes to the Hujra or of the house the troubled party and tosses himself at his feet, along these lines conceding his issue and asking

\footnotetext{
${ }^{6}$ likewise alludes to the entire assortment of individuals who make up this gathering of arbiters. This happens when Qawmi Jirga makes a Prikra that relative of standard send a Nanawate to the casualty's home. This comprises of a gathering of individuals that incorporate Speengiri, Torsary (female family members of the wrongdoer holding a Quran) and Speenpatkian close by with guilty party's direct relations (and once in a while the wrongdoer himself) who carry a sheep and flour to the casualty's home.

The sheep is frequently butchered at the entryway of the casualty's home. Then, at that point, individuals from Nanawate request consent to go into the house. Once inside the house, they look for pardon in the interest of the guilty party. All things considered contrary to the standards of Pashtunwali to dismiss a Nanawate, the casualty's family members pardon the guilty party and the two gatherings are thus accommodated. This compromise cycle is called Rogha. What is significant in this service is that the guilty party is reaccepted to the clan after he is openly considered capable and mentioned to that what he/she has done isn't right. And yet, he/she is treated with deference as an individual tribesman. This may be an illustration of what Braithwaite (1989) calls "re-integrative disgracing" - a disgracing of the wrongdoer, which is trailed by re-tolerating him/her into the local area. Contemporary criminological writing shows that this type of disgracing is more viable in decreasing wrongdoing than 'disintegrative' disgracing that names the wrongdoer as various, evil, and bars him/her from the local area.
}

${ }^{7}$ Solha is a Pashtu word used for peaceful reconciliation among disputants. 
statement of regret or exculpate of the individual or family, whose feeling of honor he has harmed. To demonstrate his quietness and ugliness the guilty party butchers goats or sheep at the entryway venture of his victim ( $\underline{\mathrm{Ambreen}}$ et al, 2013).

\section{Modes of Nanawate}

Nanawate pre- Jirga: When a man understands his being on the wrong in harming or murdering of someone else, He enthusiastically goes to the house or the Hujra of the distressed party and tosses himself at his feet, accordingly admitting his error and asking acquittal of the individual or family, whose feeling of honor he has harmed. To demonstrate his accommodation and unpleasantness the wrongdoer butchers sheep or goats at the entryway of his adversary or casualty individual. He more often than not runs with more established individuals, relatives, ladies, and conscious individuals from society (Ambreen et al, 2013).

Nanawate post-Jirga: In this appearance of Nanawate a humble foe is overlooked and the fighting groups resume tranquil and inviting relations when a Jirga individuals choose to organize Nanawate while proclaim that a man being on the wrong in murdering or harming someone else. They goes to the house or the Hujra of the distressed party and tosses himself at his feet, along these lines checking his flaw and asking acquittal of the individual or family, whose feeling of honor he has harmed (Ambreen et al, 2013). Keeping in view the above stock of literature the present study is designed to explore the role of Nanawate as a conflict resolution process through quantitative research design.

\section{Research Questions}

- Does Nanawate is considered a symbol of Pukhtunwali?

- Does Nanawate resolve Pukhtun conflict at the macro and micro levels?

\section{The objective of the Study}

1. To highlight the demographic sketch of sampled respondents.

2. To explore the hidden custom among pukhtun's inhabitants for conflict resolution.

3. To assess the level of association among variables through quantitative research design.

4. To suggest policy recommendations in light of the present study.

\section{METHODOLOGY}

\section{Research Design \& Study area}

A cross-sectional-based research design was conducted with the sole aim to explore the role of Nanawage in the conflict resolution process among Pukhtun inhabitants in District Dir Lower Khyber Pukhtunkhwa. District dir lower comprised of 7 tehsils (sub division), however, three union councils were purposively selected i.e., Balambat, Khungi, and Rabat. The potential sampled respondents of the study were household heads particularly those elders/ Jirgmar/ religious leaders/ and those who practiced and observed Nanawate as the traditional mechanism of conflict resolution from 217 respondents as per Sekeran criteria (2003). Further, the sample size was proportionally allocated to each strata (UCs) as shown in table (1) as per the formula given by Chaudhry and Kamal (1996). A detailed structured interview schedule encompassing all the study dynamics were used as a data collection technique. Moreover, descriptive (univaraite) and inferential (bivaraite) statistics was determined to explore the association between dependent (conflict resolution) and independent variable (Nanawate) through the application of chi-square test statistics by the virtue of SPSS (20 version) respectively.

Table 1: Allocation of Sample Size to Various villages in Universe of the Study

\begin{tabular}{lll}
\hline Name of Village & House Hold Head & Sample size \\
\hline Balambat & 138 & 71 \\
\hline Khungi & 144 & 75 \\
\hline Rabbat & 138 & 71 \\
\hline Total & 420 & 217 \\
\hline
\end{tabular}

\section{Data Analysis}

The collected information were coded in Statistical Packages for Social Sciences "SPSS" version (20) for uni-variate and $\mathrm{Bi}$-Varaite analysis to analyzed the results in terms of descriptive statistics (frequency and percentage distribution) and inferential statistics (Chi-square test). Chi-square test statistics is a method used to convert the qualitative data into quantitative data (to ascertain the association between dependent and independent variables) as outlined by McCall and Robert (1975) is as follows.

$$
\mathcal{X}^{2}=\sum_{i=1}^{r} \sum_{j=1}^{c} \frac{\left(O_{i j}-e_{i j}\right)^{2}}{e_{i j}}
$$


Where, "ojk" was the observed frequency in the cell corresponding to the intersection of the J-throw and K-th column, " $\mathrm{r}$ " the number of rows "c" the number of columns.

\section{RESULTS AND DISCUSSIONS}

\section{Socio-economic sketch of the sampled respondents}

Based on demographic characteristics of the sampled respondents i.e. Age, family type, family size, education and qualification, occupation, monthly income, and expenditure which explicit the social status of the inhabitants and practicing Nanawate as a tool for conflict resolution. Table 2 disclosed that the majority of the respondents $33 \%$ belonged to the age group 51-60 years, 64\% were married, 43.8\% were unemployed, and $43.3 \%$ of the sampled respondents were from a joint family system. Moreover, $69.1 \%$ of the respondents illustrated their family size containing 11-15 family members, concerning the literacy level of the respondents $41.9 \%$ respondents were illiterate and $46.1 \%$ of the sampled respondents had their monthly income as PKR 11,000-20,000 respectively.

Table 2: Demographic sketch of the sampled respondents

\begin{tabular}{|c|c|}
\hline Characteristics & Frequency (\%) \\
\hline \multicolumn{2}{|l|}{ Age } \\
\hline $18-30$ & $27(13.0)$ \\
\hline $31-40$ & $44(18.4)$ \\
\hline $41-50$ & $25(12.1)$ \\
\hline $51-60$ & $71(33.1)$ \\
\hline Above 60 & $50(23.4)$ \\
\hline \multicolumn{2}{|l|}{ Marital Status } \\
\hline Married & $139(64.1)$ \\
\hline Unmarried & $78(35.9)$ \\
\hline \multicolumn{2}{|l|}{ Occupation } \\
\hline Unemployed & $95(43.8)$ \\
\hline Mason & $9(4.1)$ \\
\hline Shopkeeper & $13(6.0)$ \\
\hline Tailor & $10(4.6)$ \\
\hline Farmer & $50(23.0)$ \\
\hline Labor/Daily Wager & $18(8.3)$ \\
\hline Drier & $9(4.1)$ \\
\hline Teacher & $5(2.3)$ \\
\hline Carpenter & $8(3.7)$ \\
\hline \multicolumn{2}{|l|}{ Family Type } \\
\hline Joint & $94(43.3)$ \\
\hline Extend & $53(24.4)$ \\
\hline Nuclear & $70(32.3)$ \\
\hline \multicolumn{2}{|l|}{ Family Size } \\
\hline $2-5$ & $5 \quad(2.3)$ \\
\hline $6-10$ & $42(19.4)$ \\
\hline $11-15$ & $150(69.1)$ \\
\hline Above 16 & $20(9.2)$ \\
\hline \multicolumn{2}{|l|}{ Education } \\
\hline Illiterate & $91(41.9)$ \\
\hline Primary & $54(24.9)$ \\
\hline High School $\left(6^{\text {th }}\right.$ to $\left.19^{\text {th }}\right)$ & $32(14.7)$ \\
\hline HSSC & $11(5.1)$ \\
\hline BA & $18(8.3)$ \\
\hline Master & $10(4.6)$ \\
\hline Above Master & $1(5)$ \\
\hline \multicolumn{2}{|l|}{ Monthly Income PKR/month } \\
\hline Bellow 10,000 & $72(33.2)$ \\
\hline $11,000-20,000$ & $100(46.1)$ \\
\hline $21,000-30,000$ & $15(6.9)$ \\
\hline $31,000-40,000$ & $136.0)$ \\
\hline $41,000-50,000$ & $6(2.8)$ \\
\hline Above 50000 & $11(5.1)$ \\
\hline
\end{tabular}




\section{Perception and Association between Nanawate as a Mechanism of Conflict Resolution}

The results indicate that $98.2 \%$ of respondents were practicing Nanwate locally. Likewise, a significant $\mathrm{p}=0.058$ association was found among the practice of Nanawate at locally and conflict resolution. It could be deduced from these findings that Nanwate is a powerful mechanism during and after disputes resolution among local inhabitants of the area. These results were in line with the outcome of Dawar, (2017), who disclosed that the level of trust among Thakalis is high and not very many cases go to the court for determination and their overriding stress is the protection of society's overwhelming institutional practices. In the far-western area of Nepal, Mukhiyas are powerful in intervening in a wide range of neighborhood clashes inside of the group. Concerning to the practice of Nanawate by the family members, a high proportion $(97.7 \%$; 0.040) association was found between Nanawate is practiced at the familial level for conflict resolution. These outcomes were also in line with the preceding as disclosed by Dahal et al., (2008), among Mukhiya framework in lower Mustang and Raja framework (realm) in upper Mustang are old institutional game plans which gave nearby administration and determining neighborhood debate through standard laws, guidelines and qualities.

Moreover, Nanawate practice is satisfactory in terms of conflict resolution as disclosed by $93 \%$ with 0.003 association was found between the aforementioned attributes. It could be deduced from such findings that, Nanawate is widely practiced due to the normative obligation which every Pushtu must entail and satisfied with the results (Sanaullah, 2020). Likewise, Nanawate is more revered than the court system, a major portion $97.7 \%$ of the sampled respondents illustrated that Nanawate is more revered than the court system; along with a significant (0.040) association were found between the above-mentioned variables. Nanawate is more revered than the court system due to the persistent nature of easy access with the collaboration of inexpensive. The results are proved by Dahal et al., (2008), who dismantled that the common traditional approaches adopted in Nepal comprised "Panchakachari" (a group of five eminent persons). In this system, five trustworthy persons of the village study the causes of conflict, carry out discussions, exchange information and opinion, collect in arguments and discussions, identify common points and solve it in the interest of both sides. In Nepal, small conflicts are constantly settled by using informal institutional mechanisms. Results pertaining to the appointment of mediators for Nanawate on mutual agreement, majority $98.6 \%$ of the sampled respondents favored the appointment of mediators for Nanawate on mutual agreement; along with a highly significant (0.000) relationship was found between the appointment of mediator for Nanawate on mutual agreement and conflict resolution. These results were in line with Yousaf, \& FurrukhZad (2020), who reported that the quantity of individuals for a Jirga relying upon the way of the issue. In clashes in the middle of towns and tribes, a Jirga will contain an equivalent number of Jirga individuals from both sides. In individual/family clashes, the Jirga individuals are delegated by gatherings agreement they select the persons who the gatherings trust, and the Jirga individuals are required to be fair-minded.

Concerning the Traditional mechanism of conflict resolution (Nanawate) treating everyone fairly/equally, a high portion 99\% of the sampled respondents viewed in the fever of the Traditional mechanism of conflict resolution (Nanawate) treating everyone fairly. Along with a highly significant (0.000) association was found between the aforementioned statements. It could be deduced from these findings that, Nanawate practicing at Pushtoon society is equally treated among both parties. These results is supported by Sanaullah, (2020) who explained that majority of conflicts that are considered 'private' are settled inside among Afghan more distant family that the Pashtun allude to as Kahol and the Tajik and Hazaras as Khanawada, or Khanadan. As the foundation of society,' the most seasoned man in the familygranddad is appointed undisputed power. The way that granddad/father controls the family's common sources further invigorates his situation as the primary figure of power, which is additionally unequivocally recognized by Islamic lessons. Along these lines father/granddad act a critical job in the goal of contentions that are estimated 'private' Thus, a lot of conceivably genuine questions, worried about aggressive behavior at home, separate, legacy, courses of action of relationships are settled inside the 'private' circle of the Afghan more distant family.

The highest portion of the respondents which were $95.9 \%$ illustrated that it is religiously believed to accept Nanawate, moreover, a significant (0.040) relationship were observed between the independent variable (it is religiously believed to accept Nanawate) and dependent variable (conflict resolution). Religion as an institution plays an important role to solve the issue pertaining to the individual, familial and community levels. These results were supported by Dahal et al (2008), who explained that in Nepal the rules to determine clashes are not lawful and real proof and records, but rather are restricting through strict vows for the sake of God and contacting heavenly hallowed books or images. Such easygoing peace promotion techniques blend neighborhood customs, give a feeling of equity, and remind strict sentiments to stay away from replication of wrongdoing - no less incredible than managerial proper strategies.

Again concerning religiously believed that rejection of Nanawate will bring damnation on their family the majority $93.1 \%$ of the sampled respondents were in viewed in a fever of it religiously believed that rejection of Nanawate will bring damnation on their family. Furthermore, a significant association (0.003) was observed between the aforementioned variable and conflict resolution. Religion plays an important mediator in terms of conflict resolution due to culturally embedded since its dawn. Moreover, the negation from religious doctrine is considered as norms violation which further provoked to negative sanction from society and community. These results were also supported by Braithwaite (1989) and Yousaf, \& FurrukhZad (2020), who explained that as it is opposite the philosophy of Pashtunwali to reject a Nanawate, the casualty's affiliated exoneration the transgressor and the two gatherings are resultantly accommodated. The cycle of compromise is called Rogha. What is significant in this activity is that the guilty 
party is re-acknowledged to the clan after he is freely proclaimed mindful and concedes that what he/she has done isn't right. At a similar time, the person is confronted with deference as an individual tribesman.

Table 3: Showing the Univaraite and bivaraite level among Variables

\begin{tabular}{|c|c|c|c|c|}
\hline \multirow[t]{2}{*}{ Attribute } & \multicolumn{3}{|c|}{ Univariate analysis } & \multirow{2}{*}{$\begin{array}{c}\text { Indexation of Dependent variable } \\
\text { Statistics i.e., } \mathbf{X}^{2} \text { and ( } P \text { value) } \\
\end{array}$} \\
\hline & Yes & No & Uncertain & \\
\hline $\begin{array}{l}\text { Nanawate practicing by local } \\
\text { people in the area }\end{array}$ & $213(98.2)$ & $0(0.0)$ & $4(1.8)$ & $\chi 2=6.356(0.058)$ \\
\hline $\begin{array}{l}\text { Practice of Nanawate by the } \\
\text { family members }\end{array}$ & $212(97.7)$ & $0(0.0)$ & $5(2.3)$ & $\chi^{2}=0.455(0.040)$ \\
\hline $\begin{array}{l}\text { Level of satisfaction over } \\
\text { Nanawate }\end{array}$ & $201(93.0)$ & $5(1.9)$ & $11(5.1)$ & $\chi 2=9.084(0.003)$ \\
\hline $\begin{array}{l}\text { Nanawate is more revered } \\
\text { than court system }\end{array}$ & $212(97.7)$ & $0(0.0)$ & $5(2.3)$ & $\chi^{2}=5.455(0.040)$ \\
\hline $\begin{array}{llr}\text { Mediators for } & \text { Nanawate are } \\
\text { appointed } & \text { by mutual } \\
\text { agreement } & & \\
\end{array}$ & $214(98.6)$ & $0(0.0)$ & $3(1.4)$ & $\chi^{2}=112.987(0.000)$ \\
\hline $\begin{array}{l}\text { Nanawate treating everyone } \\
\text { fairly }\end{array}$ & $215(99.0)$ & $1(0.5)$ & $1(0.5)$ & $\chi^{2}=41.722(0.000)$ \\
\hline $\begin{array}{l}\text { Nanwate is religiously to be } \\
\text { accepted }\end{array}$ & $208(95.9)$ & $2(0.9)$ & $7(3.2)$ & $\chi 2=0.034(0.040)$ \\
\hline $\begin{array}{l}\text { Religiously believed that } \\
\text { rejection of Nanawate will } \\
\text { bring damnation on their } \\
\text { family }\end{array}$ & $202(93.1)$ & $4(1.8)$ & $11(5.1)$ & $\chi 2=9.084(0.003)$ \\
\hline
\end{tabular}

*Number in the table represents frequencies and number in parenthesis represents percentage proportion of the respondents.

\section{CONCLUSION \& RECOMMENDATIONS}

A cross-sectional-based study was conducted to overlook the hidden custom among Pakhtune society for conflict resolution at the individual, familial, community, and societal levels. Based on the result Nanawate is widely practiced by Pakhtune inhabitants locally by the virtue of gray beard (Speengeries), religious clergies (Mullas), and family head. Moreover, religion also plays a vital role as a mediator among two party's conflicts through the perpetuation of Nanawate as it to be believed satisfactory, while not a rejection of Nanawate by someone may consider as damnation on that party who negated the contribution of the religious institution. Exposing the role of Nanawate in terms of conflict resolution particularly is the order of the day through awareness and social media at the macro (government/nongovernment sectors) and micro-level (familial and community level), with the collaboration of by giving a legal status in judiciary system will dethrone the conflicting situation among local inhabitants through the hidden custom of Nanawate were put forwarded some of the recommendations in light of the present study.

ACKNOWLEDGEMENT: Apart from the work of the author (s) the respondents of this study is also valued for giving their valuable view.

\section{AUTHORS CONTRIBUTION}

Habib ur Rahman: is the principal author of this article, designing the whole and wrote the article.

Dr. Humaira Jamal: Supervisor and get insight into the application of the statistical tools with a keen interest in the exploration of the hidden dilemma among Pukhtun society- as like conflict and their solution through a traditional mechanism.

Younas Khan: Supported and worked as a harnessing agent of the research article and supported in designing and proofreading.

Waqar Ahmad: Facilitated in statistical analysis of the collected data.

Abdullah: Provided support and facilitated the author in data collection from the field.

\section{REFERENCES}

1. Afsar, S., Samples, C., \& Wood, T. (2008). The Taliban: An organizational analysis. Retrieved from https://apps.dtic.mil/dtic/tr/fulltext/u2/a485136.pdf

2. Ahmed, A. (2013). Thistle and Drone: America's War on Terror or War on Tribal Islam. Vanguard Book, Lahore. 
3. Ahmed, Z. S., \& Yousaf, F. (2018). Pashtun Jirgas, their potential in Pak-Afghan reconciliation and national reconstruction. South Asia Research, 38(1), 57-74. https://doi.org/10.1177/0262728017748382

4. Alam, J., \& Ali, S. R. (2013). Honor: An Uncompromised Feature of Afridi Tribe. JL \& Soc'y, 44, 115.

5. Alam, J., Ali, S. R., Shah, M., \& Jamal, H. (2014). Feud: An Arena of Pakhtunwali and Violence among Pakhtun of Afridi Tribe. FWU Journal of Social Sciences, 8(2), 37.

6. Ambreen, M., \& Mohyuddin, A. (2013). Power structure and conflict resolution among pashtun tribes (a case study of zandra village in balochistan). Power, 2(1). Retrived from https://www.researchgate.net/pub lication/259480793 POWER STRUCTURE_AND_CONFLICT_RESOLUTION_AMONG_PASHTUN_TRI BES_A_CASE_STUDY_OF_ZANDRA_VILLAGE_IN_BALOCHISTAN

7. Atayee, M. I. (1979). A Dictionary of the Terminology of Pashtun's Tribal Customary Law and Usages. International Centre for Pashto Studies, Academy of Sciences of Afghanistan.

8. Beattie, H. (2011). Negotiations with the tribes of Waziristan 1849-1914-The British experience. The journal of imperial and commonwealth history, 39(4), 571-587. https://doi.org/10.1080/03086534.2011.615597

9. Braithwaite, J. (1989). Crime, shame and reintegration. Cambridge University Press. https://doi.org/10.1017/ CBO9780511804618

10. Braithwaite, J., \& D'costa, B. (2018). Cascades of violence war, crime and peacebuilding across South Asia. Acton, ACT: ANU Press. https://doi.org/10.22459/CV.02.2018

11. Brigg, M., and P. O. Walker. 2016. "Indigeneity and Peace." In The Palgrave Handbook of Disciplinary and Regional Approaches to Peace, edited by O. P. Richmond, S. Pogodda, and J. Ramovic, 259-271. London, UK: Palgrave Macmillan. https://doi.org/10.1007/978-1-137-40761-0_20

12. Cabanes, P. (2017). Philippines: The indigenous conflict resolution practices of the higaunon tribe. Conflict Studies Quarterly, 19, 65-84.

13. Coughlin, C. (2013). Churchill's first war. Basingstoke, Hampshire: Pan Macmillan UK. Retrieved from https://www. panmacmillan.com/authors/con-coughlin/churchills-first-war/9780230771529

14. Dahal, D. R., \& Bhatta, C. D. (2008). The relevance of local conflict resolution mechanisms for systemic conflict transformation in Nepal. Berghof foundation for peace support.

15. Dawar,S and Khan, H. (2017). Riwaj The Way of Life in Tribal Areas.https:// shahmbookco.com/product/ riwajthe-way-of-life-in-tribal-areas/

16. Dupree, L. (1980). Afghanistan Princeton University Press. Princeton, New Jersey.

17. Hadid, D., Sattar, A. (2018). Caught between the military and militants, Pakistan's Pashtuns fight for rights. Retrieved from https://www.npr.org/sections/parallels/2018/04/07/598045758/caught-between-the-military-and -militants-pakistans-pashtuns-fight-for-rights

18. Khan, M. A., \& Saeed, F. (2017). Constitutional spaces for leadership in FATA: Analysis of leadership crisis and conflict management. Pakistan Perspective, 22(1).

19. Khan, Y., Shah, M., Fakhrudin, N. K., Ullah, A., \& Rehan, Z. U. (2018). Excluding Women's from Political Institution through Educational Deprivation. International Journal of Research and Innovation in Social Science (IJRISS), 3, 249-255.

20. Khan, Y., Shah, M., Ud-din, F., Ullah, Z., \& Rehan, S. (2018a). Familial Impediments to Women Political Status in Pukhtun Society. Anthropol, 6(208), 2332-0915. https://doi.org/10.4172/2332-0915.1000208

21. Kilcullen, D. J. (2009). Terrain tribes and terrorists: Pakistan, 2006-2008. Brookings Counterinsurgency and Pakistan Paper Series, 3.

22. Must, E. (2018). Structural inequality, natural resources and mobilization in southern Tanzania. African Affairs, 117, 83-108. https://doi.org/10.1093/afraf/adx048

23. Peter, S. (2017). Nigeria: ADR and the oku iboku-ikot offiong conflict (1987-2005). Conflict Studies Quarterly, 19, 3-22.

24. Sanaullah. (2020). Effectiveness of civilians' survival strategies: insights from the Taliban's insurgency (200709) in Swat Valley, Pakistan. Global Change, Peace \& Security, 32(3), 275-296. https://doi.org/10.1080 /14781158.2020.1809366

25. Sekaran, U. (2003). Research Methods for Business Students. Book.

26. Siddique, A. (2014). The Pashtun question: The unresolved key to the future of Pakistan and Afghanistan. Hurst \& Company Limited.

27. Taizi, S. (2007). Jirga system in tribal life. Area Study Center (Russia, China and Central Asia). University of Peshawar.

28. The International Legal Foundation (2004, September). The Customary Laws of Afghanistan, Kabul: ILF, 2004. Available from http://www.usip.org/files/file/ilf_customary law afghanistan.pdf

29. Wylly, H. C. (1912). From the Black Mountain to Waziristan: being an account of the border countries and the more turbulent of the tribes controlled by the North-West Frontier Province, and of our military relations with them in the past. Macmillan. https://doi.org/10.2307/1778225

30. Yousaf, F., \& FurrukhZad, S. (2020). Pashtun Jirga and prospects of peace and conflict resolution in Pakistan's 'tribal'frontier. Third World Quarterly, 41(7), 1200-1217. https://doi.org/10.1080/01436597.2020.1760088 
31. Yousaf, F., \& Poncian, J. (2018). Detriments of colonialism on indigenous conflict resolution: An analysis of Pakistan and Tanzania. Contemporary Justice Review, 21(4), 455-473. https://doi.org/10.1080/1 $\underline{0282580.2018 .1532795}$

32. Yousaf, F., Rasheed, H., \& Gul, I. (2018). FATA tribes: Finally out of colonial clutches? Past, present and future. Center for Research and Security Studies. Retrieved from http://crss.pk/wp-content luploads/2018/07/FATA-Tribes-Finally-Out-of-Colonial-Clutches.pdf

33. Yousufzai, H. M., \& Gohar, A. (2005). Towards Understanding Pukhtoon Jirga: An Indigenous Way of Peace building and More... Just Peace International. https://doi.org/10.4324/9780203106884-18 